\title{
DISTAL DELETION OF THE SHORT ARM OF CHROMOSOME NO. 10: A CASE REPORT
}

\author{
Shigehiro OKa, ${ }^{1,2}$ Hiroyuki NaKano, ${ }^{2}$ Tsunehiro YoKochI, ${ }^{2}$ \\ Ken UEDA, ${ }^{2}$ and Akihiro SAITO ${ }^{2}$ \\ ${ }^{1}$ Department of Pediatrics, Hamamatsu University, School of Medicine, \\ 3600 Handa-cho, Hamamatsu, Shizuoka 431-31, Japan \\ ${ }^{2}$ Shizuoka Children's Hospital, Shizuoka, Japan
}

\begin{abstract}
Summary Distal deletion of the short arm of chromosome No. 10 in a psychomotor retarded and malformed boy is described. His karyotype was $46, \mathrm{XY}$, del(10)(p13), i.e., partial monosomic for a distal segment of the short arm of No. 10. The clinical features included microcephaly, hypertelorism, depressed nasal bridge, bilateral epicanthus, small palpebral fissures, low set ears with small auricles, wide-spaced nipples and congenital heart disease.
\end{abstract}

\section{INTRODUCTION}

Partial deletion of the short arm of chromosome No. 10 had been first reported by Elliott et al., since then 6 more cases were submitted (Elliott et al., 1970; Francke et al., 1975; Shokeir et al., 1975; Berger et al., 1977; Prieto et al., 1978; Bourrouillou et al., 1981; Fryns et al., 1981). This paper describes another case monosomic for a distal segment of the short arm of No. 10 with multiple congenital malformations.

\section{CASE REPORT}

The propositus, a male infant, was born at 37 weeks of gestation to healthy and non-consanguineous parents as the second child with a normal and healthy elder sister. At birth, he scored 7 on the Apgar score. The birth weight was $2,420 \mathrm{~g}$, the length $46 \mathrm{~cm}$, the head circumference $32 \mathrm{~cm}$ and the chest circumference $28 \mathrm{~cm}$. Cyanosis was present at birth. Due to poor sucking, he was maintained on tube feeding during the neonatal period. Neonatal jaundice was severe, which was managed with a phototherapy. He spent 2 months in an incubator since birth. Psychomotor development was retarded and general cyanosis persisted. The general growth was delayed. It took 7 months for acquisition of head control, 1 year for

Received September 9, 1982 
accomplishment of rolling over on bed and 1 year and 5 months for assuming a sitting position. Ever since he has been able neither to support an erect posture nor to toddle until the age of 2 years and 5 months. His speech is still composed only of babbling.

Because of a heart murmur and cyanosis, he was hospitalized at age 1 year and 1 month, where under the diagnosis of tetralogy of Fallot and hypoplasia of the pulmonary artery, the left Blalock-Taussig shunt operation was performed. Although cyanosis remitted, the follow-up is continued.

The present clinical status ( 2 years and 5 months of age) consists of psychomotor retardation, general cyanosis, heart murmur, microcephaly, bilateral small palpebral fissures, hypertelorism, bilateral epicanthus, depressed nasal bridge, hypoplasia of philtrum, bilateral low set retroverted ears with small auricles, bilateral stenosis of meatus acusticus externus, high arched palate, small mouth and micrognathia (Fig. 1). The trunk showed wide-spaced nipples, navel hernia and atopic dermatitis with retentio testis on the right side. Dermatoglyphics showed the presence of simian creases on the right palma and dactylographics showed ulnar loops on 8 fingers. Axial triradii were closer to the ulnar side bilaterally ( $\mathrm{t}^{\mathrm{b}}$ : border triradius).

Cranial computerized tomography disclosed no abnormality.

Antimongoloid slant was not observed.

Preoperative laboratory examinations were: red cell count 7.52-million, hemoglobin $21.1 \mathrm{~g} / \mathrm{dl}$, hematocrit $67 \%$ and white cell count 6,700 with insufficiency of

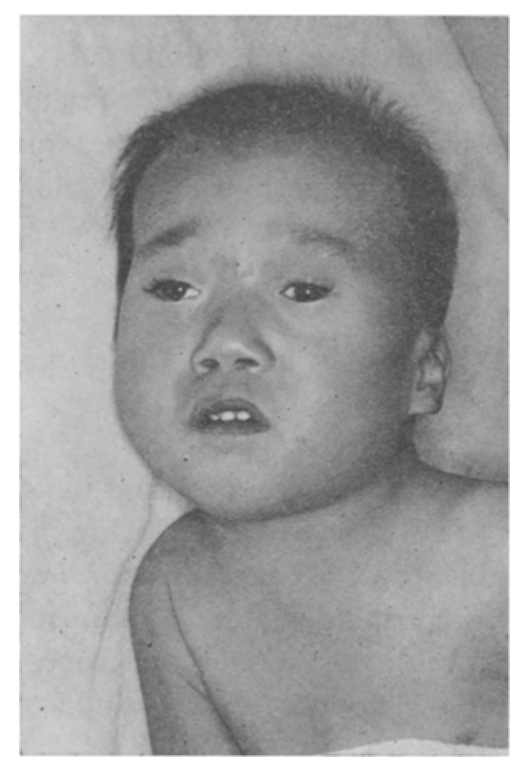

Fig. 1. The propositus at 2 years and 5 months of age.

Jpn. J. Human Genet. 
iron, i.e., the serum iron content $29 \mu \mathrm{g} / \mathrm{dl}$ and TIBC $496 \mu \mathrm{g} / \mathrm{dl}$. Postoperative examination showed mild improvement with a red cell count of 6.31-million, hemoglobin of $17.1 \mathrm{~g} / \mathrm{d} 1$ and hematocrit of $52.6 \%$. Blood-chemistry revealed: $\mathrm{Na} 145$ $\mathrm{mEq} /$ liter, $\mathrm{K} 5.1 \mathrm{mEq} /$ liter, $\mathrm{Cl} 111 \mathrm{mEq} /$ liter, urea nitrogen $31 \mathrm{mg} / \mathrm{dl}$, uric acid 3.7 mg/dl, GOT 53 IU/liter, GPT 14 IU/liter, LDH 138 IU/liter, CPK 103 IU/liter, total proteins $6.8 \mathrm{~g} / \mathrm{dl}$ and $\mathrm{A} / \mathrm{G} 2.2$. Although urea nitrogen and GOT were slightly elevated, urea nitrogen later returned to 11 which is within the normal range but

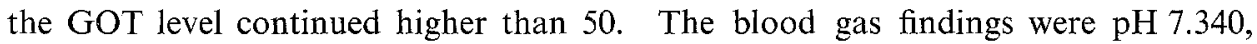
$\mathrm{PCO}_{2} 41.1 \mathrm{mmHg}, \mathrm{PO}_{2} 34.1 \mathrm{mmHg}, \mathrm{BE}-2.2 \mathrm{mEq} /$ liter and $\mathrm{HCO}_{3} 21.5 \mathrm{mEq} / \mathrm{liter}$ which were amended postoperatively to $\mathrm{pH} 7.355, \mathrm{PCO}_{2} 44.9 \mathrm{mmHg}, \mathrm{PO}_{2} 36.3$ $\mathrm{mmHg}, \mathrm{BE}+0.0 \mathrm{mEq} /$ liter and $\mathrm{HCO}_{3} 24.4 \mathrm{mEq} /$ liter. Urinalysis produced no abnormality.

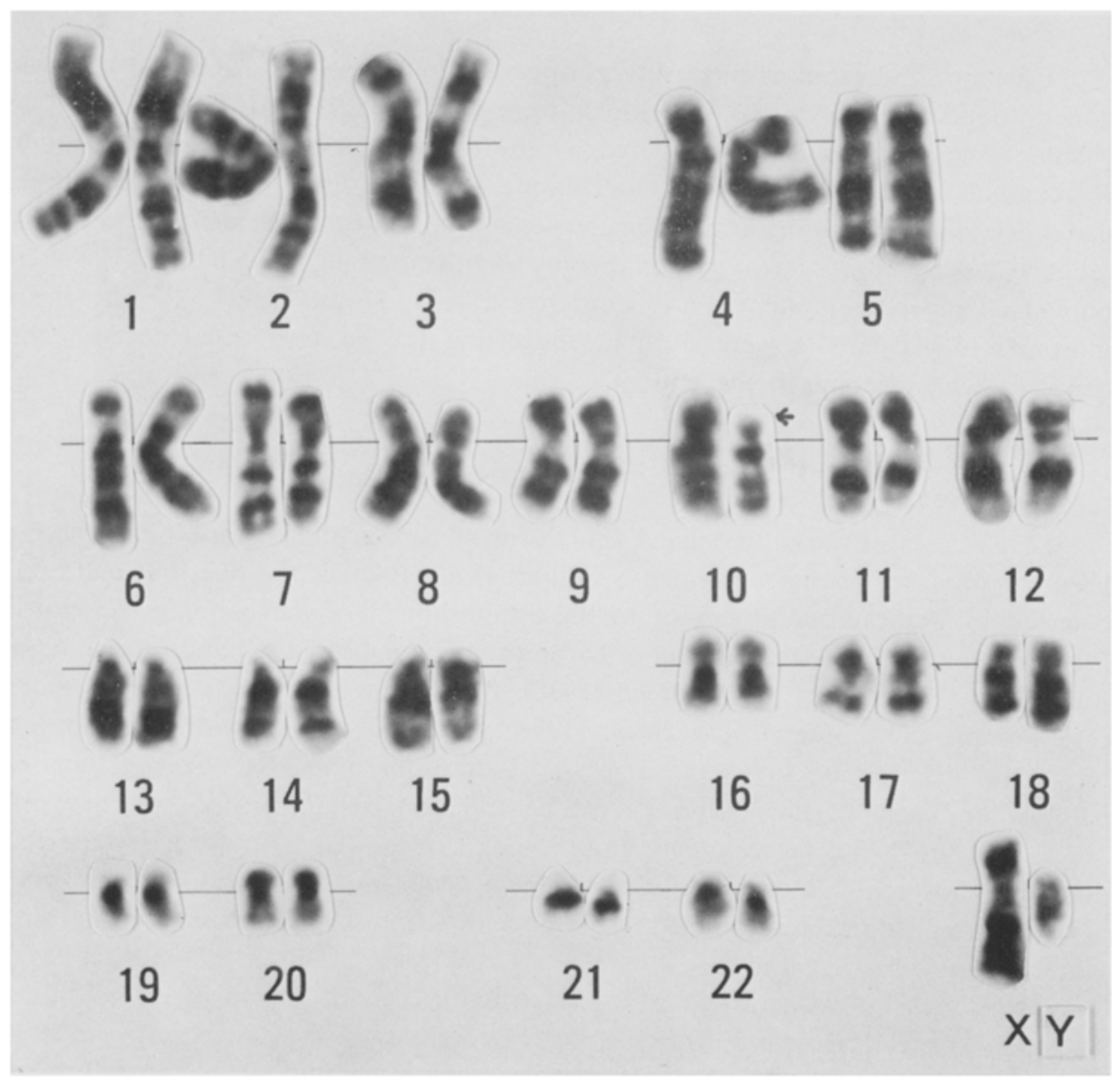

Fig. 2. G banding of propositus' karyotype. 


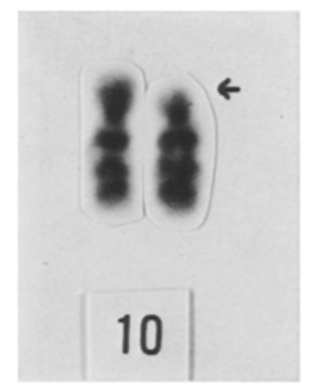

Fig. 3. Chromosome pair No. 10 (G-band). Arrow, break point p13.

\section{CYTOGENETIC STUDY}

Chromosome examination using peripheral blood was performed. PHA was added to peripheral lymphocytes which were incubated at $37^{\circ} \mathrm{C}$ for $72 \mathrm{hr}$. The chromosome specimens were prepared by the modified trypsin Giemsa technique (Nakagome et al., 1973) and the Q-technique. As a result of banding technique, distal deletion of the short arm of chromosome No. 10 became evident. The break point was p13. The karyotype was thereby identified as $46, \mathrm{XY}$, del(10)(p13), based on Paris Conference system (Paris Conference, 1971) (Figs. 2 and 3). The chromosomes of his parents were normal, suggesting the de novo occurrence of the abnormal chromosome in the patient.

\section{DISCUSSION}

Seven cases of partially deleted short arm of chromosome No. 10 have so far been reported. The case described by Elliott et al. (1970) is the one that had been detected by autoradiography prior to the establishment of the banding technique. Identification of short arm deletion of chromosome No. 10 by the banding technique was first achieved by Francke et al. (1975), which was later followed by 5 more case reports. Of these, Prieto et al. (1978) presented a case with, in addition to partial deletion of the short arm of chromosome No. 10, the presence of surplus long arm of chromosome No. 12 and reciprocal translocation between No. 2 and No. 4 and between No. 9 and No. 13. His case, therefore, represented dual chromosomal abnormalities in combination of partial deletion of the short arm of chromosome No. 10 and the presence of surplus long arm of chromosome No. 12.

Two break points, p13 and p14, existed in the deleted region of chromosome No. 10. The clinical symptoms that occurred commonly were advanced psychomotor retardation, microcephaly, brain anomalies, antimongoloid slant, hypertelorism, epicanthus, depressed nasal bridge, micrognathia, low set ears with small auricles, 
wide-spaced nipples, congenital heart disease, deformity of nephrourinary duct (Table 1). Necropsy cases demonstrated commonly either the absence or hypoplasia of olfactory bulbs in brain anomalies.

Table 1. Clinical features of partial monosomy for $10 \mathrm{p}$.

\begin{tabular}{|c|c|c|c|c|c|c|c|}
\hline & $\begin{array}{l}\text { Elliott } \\
\text { et al. }\end{array}$ & $\begin{array}{l}\text { Francke } \\
\text { et al. }\end{array}$ & $\begin{array}{l}\text { Shokeir } \\
\text { et al. }\end{array}$ & $\begin{array}{l}\text { Berger } \\
\text { et al. }\end{array}$ & $\begin{array}{l}\text { Bourro- } \\
\text { uillou } \\
\text { et al. }\end{array}$ & $\begin{array}{l}\text { Fryns } \\
\text { et al. }\end{array}$ & $\begin{array}{l}\text { Present } \\
\text { case }\end{array}$ \\
\hline Break point & $? 10 \mathrm{p}-$ & $\mathrm{p} 13$ & $\mathrm{p} 13$ & $\mathrm{p} 13$ & p14 & p14 & p13 \\
\hline & female & female & male & male & male & female & male \\
\hline Parental age $(m, f)$ & 25,34 & 25,25 & 22,22 & 38,49 & 27,31 & 23,23 & 24,35 \\
\hline Gestational age & 35 weeks & full term & full term & $\begin{array}{l}34-35 \\
\text { weeks }\end{array}$ & full term & full term & 37 weeks \\
\hline Birth weight & $1,780 \mathrm{~g}$ & $3,300 \mathrm{~g}$ & $2,530 \mathrm{~g}$ & $2,200 \mathrm{~g}$ & $2,600 \mathrm{~g}$ & $2,200 \mathrm{~g}$ & $2,420 \mathrm{~g}$ \\
\hline Age at death & 64 days & & 13 weeks & 2 days & & & \\
\hline $\begin{array}{l}\text { Psychomotor } \\
\text { retardation }\end{array}$ & $?$ & + & $?$ & $?$ & + & $\div$ & + \\
\hline Microcephaly & & & + & & + & + & + \\
\hline Brain anomalies & + & & + & + & $+($ by $\mathrm{CT})$ & & $-($ by CT) \\
\hline Antimongoloid slant & & + & + & + & + & & - \\
\hline $\begin{array}{l}\text { Abnormalities of } \\
\text { palpebral fissures }\end{array}$ & & $\stackrel{+}{+}$ & - & & & $\stackrel{+}{+}$ & $\underset{(\mathrm{small})}{+}$ \\
\hline Hypertelorism & & - & & + & + & + & + \\
\hline Epicanthus & & + & & + & + & + & + \\
\hline $\begin{array}{l}\text { Depressed } \\
\text { nasal bridge }\end{array}$ & + & + & & + & & - & + \\
\hline High arched palate & & + & & & & + & + \\
\hline Micrognathia & + & & + & + & + & + & + (mild) \\
\hline $\begin{array}{l}\text { Abnormalities of } \\
\text { philtrum }\end{array}$ & $\stackrel{+}{+}$ & & & & & (short) & $\stackrel{+}{+}$ \\
\hline Small mouth & & - & - & & & - & + \\
\hline Low set ears & & + & + & + & + & & + \\
\hline Small auricles & & + & & + & & + & + \\
\hline $\begin{array}{l}\text { Abnormalities of } \\
\text { meatus acusticus } \\
\text { externus }\end{array}$ & & - & & & & - & $\stackrel{+}{+}$ \\
\hline Wide-spaced nipples & & + & + & + & & & + \\
\hline $\begin{array}{l}\text { Congenital heart } \\
\text { disease }\end{array}$ & + & - & + & + & + & - & + \\
\hline $\begin{array}{l}\text { Abnormalities of } \\
\text { nephro-urinary duct }\end{array}$ & + & - & + & + & - & + & (unknown) \\
\hline Navel hernia & + & - & + & + & - & & + \\
\hline Retentio testis & & & + & + & - & & + \\
\hline Simian creases & - & - & + & - & + & & + \\
\hline $\begin{array}{l}\text { Abnormalities of } \\
\text { dermatoglyphics }\end{array}$ & + & & & & & + & $\stackrel{+}{+}$ \\
\hline
\end{tabular}

CT, computerized tomography; ( $m, f)$, (mother, father). 
The present case showed no abnormality in the brain by computerized tomography. The urinalysis revealed no abnormality, but the presence of deformity of the nephrourinary system could not be confirmed, since the intravenous pyelography was not applied. Also antimongoloid slant was absent from the above enumerated common symptoms. However, there was characteristic manifestation of hypoplasia of philtrum, small palpebral fissures, small mouth, stenosis of meatus acusticus externus and dermatoglyphic $\mathrm{t}^{\mathrm{b}}$.

The present patient developed two episodes of anoxic spell due to tetralogy of Fallot. He was hospitalized because of pneumonia at age one. As Elliott et al. (1970), Shokeir et al. (1975) and Berger et al. (1977) reported death of their cases in the neonatal or infantile period, careful management is required for children with a deletion of the short arm of chromosome No. 10. The report of Francke et al. (1975) was concerned with a child at the age of 5 years probably due to the absence of congenital heart disease.

Existing case reports may not be sufficient in providing clinical evidences to allow establishment of diagnosis of the syndrome related to deletion of the short arm of chromosome No. 10. However, abnormality of palpebral fissures, small auricles and wide-spaced nipples in addition to psychomotor retardation, microcephaly, hypertelorism, antimongoloid slant, depressed nasal bridge, epicanthus and congenital heart disease seem to be the characteristic involvement that leads to suspicion of the case. However, further detailed presentation of cases is needed for diagnostic evaluation.

Acknowledgments The authors wish to express their thanks to Dr. Yasuo Nakagome, Department of Human Genetics, National Institute of Genetics, Mishima, Japan and Prof. Yoshio Igarashi, Department of Pediatrics, Hamamatsu University, School of Medicine, for encouragement.

\section{REFERENCES}

Berger, R., Larroche, J.C., and Toubas, P.L. 1977. Deletion of the short arm of chromosome No. 10. Acta Paediatr. Scand. 66: 659-662.

Bourrouillou, G., Colombies, P., Gallegos, D., Manelfe, C., and Rochiccoli, P. 1981. Monosomie partielle du bras court d'un chromosome 10: A propos d'une observation avec étude tomodensitométrique. Ann. Génét. 24: 61-64.

Elliott, D., Thomas, G.H., Condron, C.J., Khuri, N., and Richardson, F. 1970. C-group chromosome abnormality $(? 10 \mathrm{p}-)$. Occurrence in a child with multiple malformations. $A m$. $J$. Dis. Child. 119: 72-73.

Francke, U., Kernahan, C., and Bradshaw, C. 1975. Del(10)p autosomal deletion syndrome: Clinical, cytogenetic and gene marker studies. Humangenetik 26:343-351.

Fryns, J.P., De Muelenaere, A., and Van Den Berghe, H. 1981. Distal 10p deletion syndrome. Ann, Génét. 24: 189-190.

Nakagome, Y., Iinuma, K., and Taniguchi, K. 1973. Points of exchange in a human No. 5 ring chromosome. Cytogenet. Cell Genet. 12: 35-39.

Paris Conference 1971. Standardization in human cytogenetics. Birth Defects. Orig. Art. Ser., Vo. 8, No. 7, Nat. Fdtn., New York.

Prieto, F., Badia, L., Moreno, J.A., Barbero, P., and Asensi, F. 1978. 10p- syndrome associated with multiple chromosomal abnormalities. Hum. Genet, 45: 229-235.

Shokeir, M.H.K., Ray, M., Hamerton, J.L., Bauder, F., and O'Brien, H. 1975. Deletion of the short arm of chromosome No. 10. J. Med. Genet. 12: 99-113. 